\title{
LEKTUR AGAMA DALAM AKSARA LONTARA BERBAHASA BUGIS
}

\section{H. Abubakar Surur}

\section{PENDAHULUAN}

Propinsi Sulawesi Selatan didiami empat suku yang merupakan penduduk asli, masing-masing memiliki bahasa tersendiri sebagai bahasa induk, yaitu suku Bugis, Makassar, Mandar dan Suku Toraja.

Bahasa Bugis tersebar luas, bukan hanya di Sulawesi Selatan, tetapi menyebat sampai ke seluruh pelosok tanah air. Suku Bugis yang suka merantau sampai keluar negeri dengan menggunakan perahu khas yang disebut "pinisi", banyak yang mendiami negara-negara tetangga, seperti Malaysia, Singapura, Brunei, Saudi Arabia dan negara lainnya. Walaupun mereka telah menjadi warganegara pada negara atau propinsi lain yang didiaminya, mereka masih ketat menggunakan bahasa Bugis sebagai bahasa komunikasi antarmereka seharihari.

Disamping bahasa, orang Bugis memiliki juga tulisan khusus yang dikenal dengan tulisan lontara, masih tetap digunakan, baik dalam surat-menyurat, maupun dalam menyusun buku-buku termasuk lektur agama (Islam).

Penyebaran dan perkembangan Agama Islam di Sulawesi Selatan, sejak awal menggunakan bahasa Bugis dan aksara Lontara, didukung dengan kenyataan bahwa orang-orang Bugis, yang umumnya beragama Islam, lebih suka menggunakan dan mempertahankan pemakaian Bahasa Bugis sebagai sarana komunikasi intern, disamping masih banyak orang Bugis yang masih sulit berkomunikasi dengan memakai bahasa nasional, terutama mereka yang berdomisili di pedesaan.

Penjelasan Undang-Undang Dasar 1945, pasal 36 menyebutkan :

"Di daerah-daerah yang mempunyai bahasa sendiri, yang diperlihara oleh rakyatnya dengan baik dan bahasa-bahasa itu akan dihormati dan dipelihara oleh nagara. Bahasa-bahasa itupun merupakan sebahagian kebudayaan Indonesia yang hidup".

Dengan demikian, Bahasa daerah Bugis dengan aksara Lontarak yang dimilikinya sampai sekarang masih banyak beredar dan dimiliki masyarakat serta dibaca oleh penduduk yang menggunakan bahasa Bugis, bahkan masih ada yanga digunakan sebagai buku-buku rujukan di Pesantren, Madrasah Diniyah dan Majelis Taklim.

Untuk mengetahui lebih dalam, perkembangan Lektur Agama tersebut, penelitian dilakukan di Kotamadya Parepare, Kota Sengkang, Watansoppeng dan Kota Watampone, sebagai sampel yang dianggap tersedia sumber data dan tempat tinggal Ulama, pengarang Lektur Agama berbahasa Bugis dapat ditemukan. 
Pengumpulan data dilakukan melalui wawan-cara dengan Ulama pengarang, tokoh masyarakat, guru-gufu Madrasah dan penerbit. Disamping itu, peneliti melakukan juga pengamatan langsung ke Pesantren dan Madrasah Diniyah.

Pengolahan dan analisis data dilakukan dengan analisis kuantitatif dan analisis kualitatif.

\section{IDENTITAS BAHASA BUGIS}

Bahasa daerah Bugis digunakan lebih separuh penduduk yang mendiami 15 dari 23 daerah kabupaten/kotamadya di Sulawesi Selatan. Hanya lagu dan dialegnya terdapat perbedaan.

Mattulada (1976) membagi wilayah pemakaian Bahasa Bugis di Sulawesi Selatan atas empat pola masing-raasing :

Pola Pertama meliputi daerah Kabupaten Bone, Soppeng, Wajo dan Luwu. Penduduk di daerah ini menggunakan bahasa Daerah Bugis secara utuh dan meluas.

Pola kedua meliputi daerah Kabupaten Sidenreng Rappang, Pinrang, Barru dan Polewali Mamasa. Penduduk menggunakan Bahasa Bugis secara meluas juga, hanya lagu bahasanya berbeda dengan pola pertama.

Pola ketiga, meliputi daerah-daerah : Kabupaten Sinjai, Bulukumba, Maros dan Pangkep, disamping berbahasa Bugis dapat juga menggunakan bahasa Makassar, kabupaten Enrekang, masyarakatnya dapat menggunakan bahasa Bugis dan Bahasa Toraja, bahkan pembauran kedua bahasa tersebut melahirkan bahasa sendiri yang mereka namakan bahasa Duri.

Daerah Kabupaten Mamuju, penduduknya dapat berbahasa Bugis dan berbahasa Mandar.
Pola ketiga ini, penduduk daerah bersangkutan dapat menggunakan bahasa lebih dari satu bahasa daerah.

Pola keempat, meliputi Kotamadya Parepare dan Kotamadya Ujungpandang. Penduduk kedua kotamadya tersebut terdiri dari berbagai suku bangsa, tetapi mereka menggunakan bahasa Bugis disamping daerah asal mereka masingmasing.

Persebaran pemakai bahasa daerah Bugis pada tempat yang geografisnya berbeda-beda, berpengaruh terhadap aksen dan lagu bahasa dikalangan mereka, sehingga melahirkan dialek lokal.

Dialek bahasa daerah Bugis dibedakaan atas: dialek lokal dan dialek sosial. Dialek lokal dikemukakan oleh pelengkahu, meliputi supuluh dialek, masingmasing: 1) Dialek Luwu, 2) Wajo, 3) Bone, 4) Sinjai, 5) Soppeng, 6) Sidenreng, 7) Parepare, 8) Sawitto, 9) Tellumpanua, dan 10) Dialek Ugi Riawa (Pelengkahu: 1974).

Dialek Sosial, terbagi atas tiga macam, yaitu :

a. Golongan Agama, pengucapannya banyak diselingi dengan kata-kata yang berasal dari bahasa (Arab).

b. Golongan adat, lebih banyak menggunakan bahasa Bugis yang mengikuti gaya klasik, seperti yang terdapat dalam La Galigo.

c. Golongan penduduk kota, menggunakan bahasa Bugis dengan memasukkang kata-kata baru yang berasal dari bahasa Indonesia atau bahasa asing. 
Perbedaan diatek iefcsebut diatas, tidak menimbulkan kesukaran pemaharrtan antarpemakai bahasa Bugis, baik dalam percakapan sehari-hari, maUpun dalam penyampaian pesanpes.an agama, atau dalam lektur Agslma yang beredar.

\section{AKSARA LONTARA}

Huruf-huruf Bugis yang lebih dikenal dengan aksara lontara, dalam kesusasteraan Bugis telah dikenal sejak abad keenambelas, sebelum agama Islam masuk di Sulawesi Selatan. Aksara Lontara yang dikenal sekarang, adalah hasil penyederhanaan yang dilakukan oleh Daeng Pamatte, seorang Syah bandar Kerajaan Gowa pada abad XVI.

Bentuk aksara Lontara bersegi empat ditulis dalam posisi menyudut, dalam bahasa Bugis disebut huruf "sulapa appa" (segi empat). Keinukan huruf Bugis, tiap huruf dapat langsung dibaca, tergantung dari tandabaca yang mengikutinya. Adapun aksara lontara, disusun menurut alpabetisnya, sebagai berikut:

// (ka), > \& (ga), X (nga), (ngka)

$\mathbf{A}(\mathrm{pa}), X \quad$ (ba), $\mathbf{y}$ (ma), \& (mpa)

-V (ta), -V (da), (na), ^ (nra)

$<\&(\mathrm{ca}),<*(\mathrm{ja}), \wedge\left(\right.$ nya),$\wedge^{\wedge}<\mathbf{v}($ nca $)$

$\wedge($ ya $),<\wedge \quad($ ra $), \wedge 1 a), \wedge$ (wa)

$Q$ (sa), ^ ( a ),^ (ha),

Aksara tersebut di atas semua dalam bunyi seperti bersambung dengan huruf a. Apabila akan dirubah bunyinya digunakan tandabaca, sebagai berikut:

-i- tanda di atas huruf menandakan bunyi i : // (ki)

- j-tanda di bawah huruf menandakan bunyi u :^ $(\mathrm{pu})$

tanda di depan huruf menandakan

bunyi e : $\mathbf{v}^{*}(\mathrm{t} 6)$

--Itanda di belakang huruf menanda- kan bunyi o :.«<£lfco)

$2 m$ tanda di a

bunyi e : ${ }^{\wedge}$ (sej

Cara menulis dlcsara Bugis sama dengan bahasa Indonesia, hanya tiap huruf ditulis

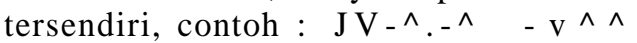
(dibaca : bicara ugi, artinya bahasa Bugis).

Huruf-huruf Bugis disebut aksara lontara, karena pada mulanya, pesanpesan yang akan disampaikan ditulis pada daun lontar dengan menggunakan lidi ijuk (Bugis :kallang). Naskah-naskah lontara kuno yang ditulis di atas daun lontar sudah sukar didapat, bahkan sudah tidak ditemukan lagi. Yang masih ditemukan adalah naskah lontara yang ditulis di atas kertas dengan tetap menggunakan "kallang", baik dalam aksara lontara maupun dalam aksara serang, yaitu bahasa Bugis yang ditulis dengan huruf Arab.

Sebuah buku poenting yang memuat kesusastraari Bugis disebut "Sure Galigo", adalah buku himpunan kesusastraan Bugis masih tulisan tangan, yang isinya berfungsi sebagai pedoman dan taata tertib kelakukan bagi kehidupan orang Bugis, seperti amanat dari orangorang bijak, petuah-petuah para raja zaman dahulu, seperti buku lontara La Toa (Mattulada, 1971 : 11).

Informasi diperoleh di lokasi penelitian yang penduduknya banyak merantau seperti Bone dan Wajo, baik dalam maupun luar negeri, diperoleh kesan, bahwa masyarakat Bugis dirantau, masih ketat mempertahankan identitas mereka sebagai orang bugis, dimanapun mereka berdomisili. Penggunaan bahasa Bugis antarmereka di perantauan tetap diperta- 
hankan. Anak-anak mereka yang lahir di rantau, tetap diajar untuk menggunakan bahasa Bugis sebagai bahasa induk, demikian pula menulis aksara lontara, bahkan mereka bangga bila disebut "ugi" (orang Bugis).

Perantau Bugis melakukan hubungan surat menyurat dengan sanak keluarga di daerah asal, masih menggunakan bahasa Bugis dan aksara lontara, begitu juga sebaliknya.

Pendatang yang mengunjungi mereka di perantauan, akan segera mendapat sambutan akrab, bila pendatang tersebut menggunakan bahasa daerah Bugis.

Mata pelajaran bahasa daerah di Sekolah Dasar dan Sekolah Menengah Pertama, menggunakan buku-buku berbahasa daerah Bugis yang ditulis dengan aksara lontara: Bahkan di sekolah-sekolah tersebut, para guru masih banyak menggunakan bahasa Bugis sebagai bahasa pengantar dalam proses belajar mengajar, baik di kelas maupun dalam melaksanakan kokurikuler di luar sekolah.

Informasi lain yang diperoleh peneliti di lokasi penelitian, bahwa pesan-pesan agama bagi umat Islam yang dilakukan para muballiq, akan mendapat sambutan dan cepat dipahami oleh masyarakat, bila muballiq menggunakan bahasa Bugis sebagai pengantar dalam bedakwah.

\section{LEKTUR AGAMA DALAM LONTARA BERBAHASA BUGIS}

Lektur agama berbahasa Bugis yang beredar di Sulawesi Selatan, dipengaruhi oleh kitab-kitab kuning (kitab berbahasa Arab) karena pada mulanya kitab kuning diterjemahkan ke dalam bahasa Bugis dengan menggunakan tulisan serang (Araba) kemudian dari tulisan serang itu beralih ke aksara lontara dan selanjutnya berkembang dalam bentuk lektur agama sejak Islam masuk ke Sulawesi Selatan sampai sekarang.

Agama Islam di Sulawesi Selatanmasuk secara bertahap melalui kerajaan; tahun 1603 di Luwu, tahun 1605 di Gowa, tahun 1616 di Bone, menyusul kerajaan-kerajaan lainnya dan sejak tahun 1630 seluruh Sulawesi Selatan telah memeluk agama Islam kecuali Tana Toraja (Dep. PK : 1980/1981).

Penyebara agama Islam di Sulawesi Selatan tiga ula dari Sumatera Barat, masing-masing : Khatib Tunggal Abdul Makmur, Khatib Sulaiman dan Khatib Bungsu. Bahasa yang mereka gunakan mengembangkan ajaran Islam adalah bahasa Melayu dengan menggunakan tulisan Arab, kemudian dialihbahasakan kedalam bahasa Bugis oleh pengikut mereka.

Penggunaan bahasa daerah Bugis sebagai bahasa pengantar untuk lektur agama yang berkembang di Sulawesi Selatan, melalui pondok pesantren dan madarasah diniyah, antara lain :

1. Madrasah Arabiyah Islamiyah Wajo di Sengkang.

Madrasah tesebut lebih populer dengan MAI, didirikan oleh seorang ulama besar keturunan Bugis, lahir dan dibesarkan serta banyak menimba ilmu agama di Mekah, yaitu Al'allamah KH. Muhammad As'ad bin KH. Abd. Rasyid, yang sengaja kembali ke Sengkang untuk mengembangkan ilmunya, pada tahun 1928. Beliau membuka perguruan agama dengan 
dua sistim, yaittf sfaiitit halaqah (pondokan) dan sistiraktassikal.

MAI menggunakan bahasa daerah Bugis sebagai bahasa pengantar dan menerjemahkan kitab-kitab kuning yang menjadi mata pelajarannya.

Santri berdatangan dari seluruh nusantara dan ada juga dari Melayu dan Benot (Malaysia).

MAI mengeluarkan banyak santri yang kemudian menjadi ulama, diantaranya ada yang mendirikan pesantren, seperti :

a. KH. Abdurrahman Ambo Dalle, pendiri Pesantren Darud Dakwah Wal Irsayd (DDI) di Parepare.

b. KH. Muh. Abduh Pabbajah, pendiri Pesantren Alfurqan di Parepare.

c. KH. Daud Ismail, pendiri pesantren Yatsrib di Watansoppeng.

d. KH. Muh. Yunus Martan (Aim), Pembina Pesantren As'adiyah Sengkang.

2. Madrasah Amir Islam di Watampone. Madrasah ini didirikan oleh Raja Bone H. Andi Mappanyukki Sultan Ibrahin, tahun 1946.

3. Pondokan Salerno di Pulau Salerno, Kabupaten Barru.

Semua pondok pesantren tersebut, menggunakan bahasa Bugis sebagai pengantar.

Madrasah-madrasah diniyah, waktu belajarnya sore hari, literaturnya adalah kitab-kitab kuning, namun pengantar yang digunakan para pengasuh/guruguru, adalah bahasa bugis, sejak dulu sampai sekarang.

\section{ULAMA PENGARANG LEKTUR AGAMA}

Adapaun ulama pengarang lektur agama dengan aksara lontara berbahasa Bugis, yang berada di lokasi pendlitian, adalah ulama yang sudah dikenal oleh masyarakat, semuanya adalah Ulama Bugis, yaitu :

1. KHM. As'ad (Aim) Sengkang 5 judul

2. KH. Abd. Rahman Ambo Dalle, Parepare 6 judul

3. KHM. Abduh Pabbajah, Parepare 8 judul.

4. KH. Haruna Rasyid, Parepare 5 judul

5. KH. Daud Ismail, Watansoppeng 6 judul

6. KHM. Yunus Martan, Sengkang 15 judul

7. KH. Hamzah Manguluang, Sengkang 1 judul

8. KH. Hamzah Badawi, Sengkang 1 judul

9. KHH. Yusuf Surur, BA 2 judul

10. KH. Djunaid Sulaiman, Watampone 5 judul.

11. KH. Abd. Malik Pompanua 7 judul.

Disamping mengarang lektur agama berbahasa Bugis, ada juga diantara mereka yang mengarang kitab-kitab dalam bahasa Arab, untuk menjadi buku pegangan di pesantren yang mereka pimpin, seperti : 1) KHM. As'ad, 2) KH. Abd. Rahman Ambo Dalle, 3) KHM. Yunus Martan, dan 4) KHM. Abduh Pabbajah.

Ilmu agama yang dikembangkan dalam karangan mereka, meliputi :1) Tafsir/Terjemahan Alquran, 2) Hadits, 3) Aqidah/Tauhid, 4) Fiqhi/Syariah, 5) Akhlak/Tasawuf, 6) Kisah-Kisah Nabi, 
7) Uraian Maulid, 8) Isra/Mi'raj, 9) Kumpulan Doa, 10) Khutbah Jum'at dan Id.

\section{PENERBIT LEKTUR AGAMA}

Sebagian besar lektur agama dengan aksara lontara berbahasa Bugis karangan terserbut, diterbitkan oleh percetakan milik ulama pengarang sendiri, yuitu :

1. Toko Buku dan Percetakan "Adil" Sengkang, menerbitkan Lektur Agama karangan KHM. Yunus Martan, KH. Daud Ismail, KH. Hamzah Manguluang dan KHM. Yusuf Surur, BA.

2. Penerbit/Percetakan "Khaeriyah" Parepare, menerbitkan karangan KH. Abd. Ramhan Ambo Dalle, KHM. Abduh Pabbajah dan KH. Haruna Rasyid.

3. Percetakan "Ibadurrahman" di Watampone, menerbitkan karangan KH. Djunaid Sulaiman.

Selain dari percetakan tersebut, diantara ulama pengarang mencetak karangannya di Ujungpandang.

Jumlah lektur agama yang diterbitkan, ketika penelitian ini dilakukan, sebanyak 37.000 eksamplar terdiri dari 15 judul. Bila dibanding dengan jumlah penduduk etnis Bugis di Sulawesi Selatan diperkirakan 5 juta, maka lektur agama yang ada masih sangat kurang. Apalagi bila dihitung orang Bugis yang berada dirantau, jelas jauh belum mencukupi kebutuhan akan lektur agama tersebut.

Apalagi pengarang lektur agama berbahasa Bugis sudah mulai uzur dan tidak produktif lagi, disamping belum ada kader ulama yang mampu melanjutkan usaha seperti yang dilakukan oleh ulamaulama tersebut.

Seorang informan di Sengkang menyatakan, bahwa lektur agama berbahasa Bugis, terutama di desa-desa, sangat bermanfaat karena bahasanya komunikatif, isi dan kandungannya langsung dipahami dan dapat dihayati oleh masyarakat yang belum mengerti betul bahasa nasional.

Lebih lanjut diungkapkan, bahwa lektur agama yang ada tidak ada lagi penambahan kecuali hanya dengan mencetak ulang, karena pengarangnya sudah sukar ditemukan.

\section{PENUTUP}

Suku Bugis, salahsatu etnis yang meniami sebagian besar Propinsi Sulawesi Selatan, adalah penganut agama Islam, yang memiliki bahasa dan aksara tersendiri, yaitu bahasa daerah Bugis dan aksara lontara.

Kedua alat komunikasi tersebut masih sangat dominan dipergunakan, baik dalam komunikasi lisan maupun tulisan.

Dalam menyampaikan ajaran agama lewat tulisan, lektur agama banyak ditulis dalam bahasa Bugis dengan aksara lontara, dikarang oleh ulama Bugis, dan masih dibaca oleh masyarakat Bugis, dimanapun mereka berada.

Peningkatan produksi lektur keagamaan yang ada belum memadai dibanding dengan pembacanya, disamping sudah ada diatara ulama pengarang tidak produktif lagi, maka perlu dipikirkan kelanjutan penerbitannya.

Kader ulama hendaknya ada yang dapat melanjutkan usaha ulama untuk memproduksi lektur agama, disamping untuk mengembangkan pemahaman ajaran agama, juga turut mempertahankan nilai budaya Bugis, sebagai bagian dari budaya nasional. 
LEKTUR AGAMA DALAM AKSARA LONTARA

\section{KEPUSTAKAAN}

Bachtiar, Harsja W. Budaya dan Manu sia Indonesia, Hanindita, Malang, 1983.

Departemen PK : Proyek Inventarisasi dan Dokumentasi Kebudayaan Daerah, Ujungpandang, 1980/-1981.

Balai Penelitian Lektur Keagamaan Ujungpandang : Laporan Hasil Penelitian Lektur Agama dalam Bahasa Daerah Bugis dan Makassar, Balai Penelitian Lektur Keagamaan, Ujungpandang, 1983/1984.

Laporan Hasil Penelitian Masuknya Islam di Sulawesi Selatan, Balai Penelitian Lektur Keagamaan, Ujungpandang, 1984/1985.

Koentjaraningrat : Masyarakat Desa di Indonesia, Universitas Indonesia, Jakarata, 1985.

Mattulada : La Toa, Gajah Mada Uni versity, Yogyakarta, 1985. 